REGULAR ARTICLE

\title{
TEST OF THE CATCH-UP HYPOTHESIS IN AFRICAN AGRICULTURAL GROWTH RATES
}

\author{
Kalu Ukpai IFEGWU $*^{1}$, Joshua Olusegun AJETOMOBI ${ }^{1}$, Babatunde Oluseyi AJIBOYE ${ }^{2}$
}

\author{
Address: \\ ${ }^{1}$ Faculty of Agricultural Sciences, Department of Agricultural Economics, Ladoke Akintola University of \\ Technology,P.M.B 4000, Ogbomoso, Oyo State, Nigeria. \\ ${ }^{2}$ College of Agricultural Sciences, Department of Agricultural Economics, Landmark University, P.M.B. 1004, Ipetu \\ Road, Omu-Aran, Kwara State, Nigeria \\ *Corresponding author's e-mail: pstkay@yahoo.com
}

\begin{abstract}
The paper tested the catch-up hypothesis in agricultural growth rates of twenty-six African countries. Panel data used was drawn from the Food and Agricultural Organization Statistics (FAOSTAT) of the United Nations. The Data Envelopment Analysis Method for measuring productivity was used to estimate productivity growth rates. The crosssection framework consisting of sigma-convergence and beta-convergence was employed to test the catching up process. Catching up is said to exist if the value of beta is negative and significant. Since catching up does not necessarily imply narrowing of national productivity inequalities, sigma-convergence which measures inequality, was estimated for the same variables. The results showed evidence of the catch-up process, but failed to find a narrowing of productivity inequalities among countries.
\end{abstract}

Keywords: Catching up, Data Envelopment Method, Agricultural Growth rates, Africa JEL: Q1, Q22, O13

\section{INTRODUCTION}

The catching up process refers to the principle that countries with relatively low technological levels are able to exploit a backlog of existing knowledge and therefore attain high productivity growth rates, while countries that operate at (near to) the technological frontier have less opportunities for high productivity growth. Therefore, countries with lower levels of technological knowledge will tend to realise higher growth rates. Implicitly, the catching up hypothesis is based on the intuition that technological change is a "public" good, i.e. it can be used "freely" by other countries besides the initial innovator. International knowledge spill-overs then bring about the tendency for countries with lower technological levels to achieve faster productivity growth (Gomulka, 1971). Any growth in output that is not explained by some index of input growth is attributed to changes in technology or more broadly total factor productivity (TFP). The concept of TFP includes improvements in techniques of production, advancement in knowledge and greater efficiency of production. Apart from these, betterment in the management practices, improvement in the quality of inputs and increase in degree of utilization of resources are also included in the concept. It is usually seen as the result of innovation by best-practice firms (farms), technological catch-up by other firms and reallocation of resources across firms and industries (Abramovitz, 1986). International technology diffusion has demonstrated to bear different consequences across countries with different levels of
TFP. Two main arguments have been put forward to explain these disparities. The first is the efficiency explanation, which argues that differences in TFP are due to inefficiency. That is, while all the countries face the same technological frontier, the observed differences reflect a distance of countries from the frontier (Basu and Weil, 1998). The second is the appropriate technology explanation, which maintains that countries tend to choose their best technology mix (i.e. they are efficient), but not all the existing technology can be adapted in their economy (Acemoglu and Zilibotti, 2001). According to Acemoglu and Zilibotti (2001), technologies invented by rich countries are not suitable for poor countries due to a different mix of input (e.g. skilled labour, machines, etc). This leads to differences in productivity levels.

In Africa, agricultural total factor productivity growth (which can be viewed as a proxy for advances in technology and innovation) has been low. Coelli and Rao (2005), estimated TFP for 93 countries of which 18 were Sub-Saharan African countries. Their results showed six African countries with TFP growth above $2 \%$ during 1980 to 2000 (Burundi, Angola, Nigeria, Ghana, Malawi and Senegal). Another two countries showed TFP growth of above 1\% during the same period (Mozambique and Cote D‘Ivoire), while other four countries had TFP growth of less than 1\% (Cameroon, Zimbabwe, Kenya and Tanzania). The rest six African countries experienced negative TFP growth during the1980 to 2000 period (Niger, Burkina Faso, Uganda, Rwanda, Guinea and Chad). Nkamleu, Gokowski and 
Kazianga (2003), calculated that on average, total factor productivity in agriculture in 10 countries in Sub-Saharan Africa decreased between 1972 and 1999 by $0.2 \%$ annually. Also, some studies estimated negative TFP growth rates for a similar period. Suhariyanto, Lusigi and Thirtle (2001), found negative agricultural productivity growth rates in Asia from 1965 to 1980 and in Africa from 1971 to 1981 . The negative agricultural total factor productivity in Africa implies that recent growth rates were based on an increase in resource base instead of adoption of new techniques. It has been observed that declining agricultural total factor productivity in many African countries can be reversed through building what are called agricultural innovation systems that provide the enabling framework not only for the adoption of existing technologies and the development of new ones that are suited for African needs. Agricultural innovation systems denote the network of economic and non-economic actors, and the linkages amongst these actors enable technological, organizational and social learning of the kind needed to devise context-specific solutions (Mapila, Kirsten and Meyer 2011). Providing an overview of the innovations system would be beyond the scope of this paper. The paper focuses on the transfer of technological innovations (knowledge) that increase total factor productivity in agriculture from one country to another, thus, facilitating the catch-up of productivity growth.

Despite being far from the innovation frontier, and thus having the potential to play catch-up, innovation in the agricultural sector in Africa has been dominated by the narrow approach of employing technology transfer and adoption theory. But successful catch-up has historically been associated not merely with adoption of existing techniques in developed countries but also with technological innovation. Technological innovation in agriculture has been playing a very important role in the productivity catch-up process. According to the United States Department of Agriculture (USDA, 2014), Brazil's soybean production grew by $9.3 \%$ from the 2008/09 crop to the 2012/13 crop, while in the USA, production grew by $0.43 \%$ over the same period through technological innovation. By 2002, the overall average yield for soybean in Brazil (2.6 metric tons/hectare) surpassed the average yield in the United States (2.4 tons/hectare or about 36 bushels per acre). Two important innovative activities were fundamental to the productivity increase in Brazil's soybean industry. They included the adoption of zero-tillage (ZT) technology for agricultural process and the development of new soybean cultivars. Similarly, at the beginning of the independence movements of the 1960s, Africa was self-sufficient in goods and a leading agricultural exporter. In contrast, Asia was the epicentre of the world food crisis. But by the mid-1960s, Asia had launched the green revolution, which added 50 million metric tonnes of grain to the world food supply each year. Although Asia struggles with issues of household food supply, it is Africa, not Asia, which bears the brunt of the world food problem (Byerlee, 1997). The concept of technological capabilities has been put forward to explain the success of the South Asian countries to catch-up, thanks to their capacity to attract and absorb technology developed abroad (Kim, 1980). Technical progress in agriculture was invariably embodied in new seeds, input suppliers, mechanisation and the emergence of new agricultural techniques and management practices. The use of modern inputs improved the marginal productivity of the land, labour and capital (Davis et al., 2007). Furthermore, in the past some other countries have caught-up with the leading international countries, others have forged ahead and several others have fallen behind (Abramovitz, 1986). Several factors contributed to the catch up of low productivity countries to high productivity ones. According to Rassekh, Panik and Kolluri (2001), two factors were central to catch up, although by no means exhaustive. The first was an adequate national innovative or learning capacity, that is, the human capital. The second was the networks of institutions that facilitated the adoption of new technologies. They maintained that catch up growth occurred by developing new ways of organizing production and distribution, and that the prerequisites for successful imitation and rapid growth included for the most part, an adequate pool of technical and managerial skills.

Empirical studies that have tested the catching up phenomenon, such as (Barro, 1991; Barro and Sala-iMartin, 1995; De Long, 1988; Mankiw, Romer and Weil 1992), have focused mainly on the developed countries and had found the catching up process only for the developed countries and not for the developing countries. These studies were based on two common assumptions: developing countries are not fundamentally different from industrialized countries and free world wide availability of technological knowledge. There has been comparatively little work that specifically examines the catching up phenomenon within the African economies. In particular, these studies tested the catching up process on the per capita income of countries. This paper tests the catching up process on the agricultural productivity growth rates of African countries. Since the process of international technological spill-over is essentially a process of adoption of new techniques at the country level. It is necessary to test the catching up hypothesis in the agricultural sector. African countries are expected to have benefitted from the importation of agricultural technologies from other countries of the world over the years.

The main objective of this paper was to test the catching up hypothesis across twenty-six African countries. This was pursued using the cross section framework consisting of sigma $(\sigma)$ and beta $(\beta)$ convergence tests. $\beta$-convergence implies catching up in the long-run, and $\sigma$-convergence represents a narrowing productivity inequalities across the countries with the passage of time. The catching up phenomenon plays an important role in explaining a tendency of national growth rates to converge (Abramovitz, 1986). Convergence in agricultural productivity, on the other hand, has important policy ramifications for national poverty reduction and increasing standards of living. By testing the catching up hypothesis in agricultural 
productivity across the African countries, a significant contribution can be made towards the economic development of African economies, which is dependent in the long run upon agricultural productivity increases. As suggested by Gutierrez (2000), low agricultural productivity constitutes a major constraint to the achievement of household food security by rural families.

The specific objectives of this paper are two folds: (i) to analyse TFP growth rates across the different countries of Africa (ii) to test whether African countries are taking part in the catching up process.

To guide research, the following hypotheses were stated (i) there is no catching up of low-productivity African countries to high-productivity ones (ii) there is no narrowing down of productivity dispersion across the African countries. The rest of the study is organized as follows. The next section highlights the material and methods used for the study. This is followed by the section that presents the results and discussion. The last section concludes.

\section{MATERIAL AND METHODS}

\section{Data and Variables}

The data used for this study were drawn from the Food and Agricultural Organization Statistics (FAOSTAT) of the United Nations for a 49-year period from 1961 to 2009 as already mentioned. The data covered output and conventional agricultural inputs (land, labour, fertilizer, tractors and livestock) of twenty-six African countries for the period of the study. These productive factors have normally been included in all estimations of agricultural productivity (Hayami and Ruttan, 1985; Gallup, Sachs and Mellinger 1999). They constitute the proximate causes of agricultural productivity differences among countries. The measures of output and inputs used for this study relate to each country. Table 1 presents the variable definitions and measurement.

\section{Estimation Method}

The catching up hypothesis test requires data on productivity levels, from which growth rates are evaluated. Productivity growth has been defined by Grosskopf (1993), as the net change in output due to change in efficiency and technical change. Where the former is understood to be the change in how far an observation is from the frontier of technology, and the latter is understood to be shifts in the production frontier. Because it takes account of all inputs used, this definition provides a comprehensive measure of performance.
There exist several methods of estimating productivity levels. The paper used the data envelopment analysis (DEA) method for measuring productivity to compute the Malmquist TFP index for each country during the period under study based on the panel dataset described in Table1. DEA is a linear programming methodology, which uses data on the input and output quantities of a group of countries to construct a piece-wise linear production frontier for each year over the data points.

Grosskopf (1993) outlined the basic procedure for deriving the total factor productivity (TFP) index. Considering two time periods $t$ and $t^{+1}$, corresponding outputs and inputs denoted by $y^{t}$ and $y^{t+1}$ and $x^{t}$ and $x^{t+1}$, the production technology model $S^{t}$, for period $t$ can be expressed as:

$S^{t}=\left\{\left(x^{t}, y^{t}\right): x^{t}\right.$ can produce $\left.y^{t}\right\}$

Similarly, for $S^{t+1}$

$S^{t+1}=\left\{\left(x^{t+1}, y^{t+1}\right): x^{t+1}\right.$ can produce $\left.y^{t+1}\right\}$

The set $S$ describes all the feasible input-output pairs at a given point in time. In a similar manner, technology can also be described with production function in period $t$ as

$$
y^{t}=\max \left\{y^{\prime t}:\left(x^{t}, y^{t}\right) \in S^{t}\right\}
$$

and in period $t+1$

$$
y^{t+1}=\max \left\{y^{\prime t+1}:\left(x^{t+1}, y^{\prime t+1}\right) \in S^{t+1}\right\}
$$

Assuming neutral disembodied technology in the Hicksian sense ( that is technology independent of input, the productivity change using technology of period t as reference is as follows:

$$
M_{0}^{t+1}\left(x^{t}, y^{t}, x^{t+1}, y^{t+1}\right)=\left[\frac{d_{0}^{t}\left(x^{t+1}, y^{t+1}\right)}{d_{0}^{t}\left(x^{t} y^{t}\right)}\right]
$$

Similarly, we can measure the TFP with period $t+1$ technology as reference as follows:

Table 1 Variable definitions and measurement

\begin{tabular}{lll}
\hline Variables & Units & Definitions \\
\hline Output & Million USD & Quantity of agricultural production(1999-2001 price) \\
Land & 1,000 hectares & Sum of arable land, permanent crops and permanent pastures. \\
Labour & 1,000 persons & Number of persons who are economically actively engaged in agriculture \\
Tractor & Pieces & Total number of agricultural tractors in use \\
Fertilizer & Metric tons & Quantity of fertilizer plant nutrient consumed (N plus P2O5 plus K2O) \\
Livestock & 1,000 heads & Weighted average of the number of animals on farm (weights are: camels 1.1; buffalo, \\
& & horses and mules 1.0; cattle and asses 0.8; sheep and goat 0.1; pigs 0.2; fowl 0.01). \\
\hline
\end{tabular}




$$
M_{0}^{t+1}\left(x^{t}, y^{t}, x^{t+1}, y^{t+1}\right)=\left[\frac{d_{0}^{t+1}\left(x^{t+1}, y^{t+1}\right)}{d_{0}^{t+1}\left(x^{t}, y^{t}\right)}\right]
$$

The Malmquist TFP index can then be derived by taking the geometric mean of the two output-based indexes in equations (5) and (6) as:

$$
M_{0}\left(x^{t}, y^{t}, x^{t}, y^{t}\right)=\left[\frac{d_{0}^{t}\left(x^{t+1}, y^{t+1}\right)}{d_{0}^{t}\left(x^{t}, y^{t}\right)} \ldots \frac{d_{0}^{t+1}\left(x^{t+1}, y^{t+1}\right)}{d_{0}^{t+1}\left(x^{t}, y^{t}\right)}\right]^{1 / 2}
$$

where $d_{0}^{t}\left(x^{t}, y^{t}\right)$ is the output distance for year $t$, which is defined as the ratio of observed output to the maximum output, $y$ producible with given technology and input vectors, $x$ (Shephard, 1970). The superscript is the value of the output distance evaluated input-output of year $t+1$ using technology of year $t$.

Equation (7) can be decomposed into the following two components namely: efficiency change (effch), and technical change (techch). Efficiency change is related to activities which employ the current amount of inputs more efficiently between two periods $t+1$ and $t$, while technical change is related to applications of new production technology and knowledge between the two periods $t+1$ and $t$. If the technical change is greater (or less) than one, then technological progress (regress) exists.

$$
e f f c h=\left[\frac{d_{0}^{t+1}\left(x^{t+1}, y^{t+1}\right)}{d_{o}^{t}\left(x^{t+1}, y^{t+1}\right)}\right]
$$

and

$$
\text { techch }=\left[\frac{d_{0}^{t}\left(x^{t+1}, y^{t+1}\right)}{d_{0}^{t}\left(x^{t+1}, y^{t+1}\right)} X \frac{d_{0}^{t}\left(x^{t}, y^{t}\right)}{d_{0}^{t+1}\left(x^{t}, y^{t}\right)}\right]^{1 / 2}
$$

Then, the product of the geometric means of the efficiency change (effch), and technical change (techch) is equal to the geometric mean of the Malmquist total factor productivity (tfpch) index. Improvements in agricultural total factor productivity and its components occur when the values of the indices are greater than one. The value of the index at a point in time minus one indicates the percentage of growth.

Previous studies have shown that agricultural total factor productivity change (tfpch), efficiency change (effch), and technical change (techch) are important factors explaining the differences in agricultural growth (Rosegrant, Agcaoili-Sombilla and Perez 1992).

\section{Concepts and methodology for testing the catch-up hypothesis}

The major theories providing a rationale for the catching up hypothesis include technology transfer and the neoclassical growth model. According to the technology transfer argument, the flow of technology should provide an opportunity for less advanced economies to advance rapidly toward economic conditions experienced in more advanced nations (EImslie, 1995). This argument rests on the idea that it is less costly for less advanced economies to imitate than to innovate. And because of diminishing returns to reproducible capital, an economy with a lower capital/labour ratio relative to another economy has a higher marginal productivity of capital and an opportunity to grow faster. The model predicts that differences in total factor productivity among economies with similar steady-state parameters, such as saving rates and human capital growth rates must be transitory, which in the long-run should lead to convergence of economies. Convergence implies a tendency for countries with low levels of productivity at the beginning of the period to grow more rapidly than those with high productivity initially. Thus, if the gap in agricultural productivity differences among countries is narrowing, the poor are catching up.

\section{Beta and Sigma Convergence}

Two primary concepts have been used to measure the presumption that low productivity countries, on average, will grow faster than high productivity ones (over the long term). The first notion, beta $(\beta)$ convergence, considers whether the correlation between a country's initial TFP level and its subsequent growth in TFP is negative. The second, sigma ( $\sigma$ ) convergence, considers whether the dispersion of TFP among countries (as measured by their standard deviation) diminishes over time. And because of diminishing returns to reproducible capital, an economy with a lower capital/labour ratio relative to another economy has a higher marginal productivity of capital and an opportunity to grow faster. Barro and Sala-i-Martin (1992) were the first to introduce the notion of $\beta$ and $\sigma$ convergence to assess whether the lagging countries grow faster than the leading ones, implying that they will catch up ( $\beta$ convergence) in the long-run, or whether the dispersion of the productivity differences diminishes ( $\sigma$ convergence) over time. They provided a framework for testing the convergence hypothesis using cross section data. This study followed the cross-section approach for convergence testing to test the absolute (unconditional) productivity growth convergence, by estimating regressions with the productivity growth rate as the dependent variable and the initial productivity level as the explanatory variable as follows:

$\Delta \bar{y}_{i, t}=\alpha+\beta y_{i, 0}+\varepsilon_{i} T$

where, $\Delta=$ is change in productivity, $\bar{y}_{i}=$ average TFP growth rate, the index $i$ refers to the individual country $(i=1, \ldots 26), \quad t=$ final year $\alpha$ and $\beta$ are parameters to be estimated, $y_{i}=$ initial TFP level , the index $i$ refers to the individual country $(i=1, \ldots . .26)$, index 0 refers to the initial year and $\varepsilon_{i}$ is an error term with a zero mean and finite variance, $T=$ time period ( $T=1961 \ldots . . . . .2009)$. Catching up is found to exist if the value of beta $(\beta)$ is negative and significant. In this case, the convergence is said to be absolute 
(unconditional) since initial level of productivity is the only independent variable used. In contrast, if the value of $\beta>0$, divergence exists.

The sigma $(\sigma)$ convergence test, on the other hand measures the dispersion of productivity levels over time across a group of countries. Sigma convergence concept can be tested by estimating the cross-sectional standard deviations of the log of TFP. Sigma convergence holds if the standard deviations of the log of TFP decrease over time. The evidence of sigma convergence is useful, since one can observe periods of convergence or divergence through time. The above two measures are complementary, but not excludable. The existence of Beta convergence is a necessary condition, but not sufficient for sigma convergence to occur. There could be high intra-distribution mobility that leads to Beta convergence, but still does not guarantee a reduction in the dispersion distribution (Thirtle et al., 2003).

\section{RESULTS AND DISCUSSION}

\section{Productivity Growth Rates}

The Data Envelopment Analysis (computer) progamme (DEAP) developed by Coelli (1996) was used to calculate the TFP Malmquist index and its components: technical efficiency change and technical changes over the entire period for each country as presented in Table 2. It should be recalled that if the value of the Malmquist index or any of its components is less than one, it implies regress between two adjacent periods, whereas values greater than 1 imply progress or improvement. In order to obtain the magnitude of growth, the values of Malmquist indices or any of its components can be subtracted from 1. The values of the indices capture productivity relative to the best performers. Table 2 indicates that twelve of the twenty-six countries of Africa had negative TFP growth rates over the 1961-2009 period (Algeria, Egypt, Libya, Morocco, Tunisia, Burkina Faso, Gambia, Niger, Senegal, Sudan, Burundi and Kenya).Tanzania had an agricultural TFP growth rate below 1\%. Six had TFP growth rates below 10\% (Uganda, Benin, Cote d'Ivoire and Ghana). While three experienced TFP growth rates above 10\% (Guinea, Nigeria, and Togo). Both Malawi and Mozambique had TFP growth rates above 20\%. Four had TFP growth rates above $40 \%$ (Namibia, South Africa, Zambia and Zimbabwe). The highest productivity growth for the period 1961-2009 was found in the southern countries of Africa-Zimbabwe (52.8\%), Zambia (51.9\%), South Africa (47.1\%), Namibia (42.1\%), Mozambique (29.8\%) and Malawi (24.3\%). This was followed by African countries of the Gulf of GuineaTogo (19.4\%), Nigeria (16.2\%), Guinea (13.1\%), Ghana (8.0\%), Cote d'Ivoire (6.7\%), Benin (4.8\%), Uganda (3.7\%). The results of negative TFP growth rates are consistent with Suhariyanto, Lusigi and Thirtle (2001). They found negative agricultural productivity growth rates in Africa from 1971 to 1981. Coelli and Rao (2005) also found similar results for some African countries during the1980 to 2000 period. These results indicate that agricultural output in those African countries grew by an increase in use of resources of land, labour and capital inputs. Positive TFP growth rates in the other countries were by advances in technical change. The support for positive agricultural TFP growth rates in African countries in this study is in line with Nkamleu, Gokowski and Kazianga (2003) who estimated total factor productivity in agriculture in the countries of sub Saharan Africa between 1972 and 1999 and found an average positive TFP growth rate of $0.2 \%$. The interesting question is, of course, whether the gap in agricultural productivity differences among countries is narrowing, that is, whether the low productivity countries are catching up with the high productivity countries.

\section{Catching Up Test}

The catching up test was conducted by estimating regressions with the growth rate as the dependent variable and the initial level of productivity as the explanatory variable as in equation (1). Catching up exists if the value of $\beta$ is negative and significant. On the other hand, if $\beta$ is positive there is lagging behind among countries. The results of the catching up test (unconditional $\beta$ convergence) are presented in Table 3. The table shows that for the study period, the estimated parameter $\beta$, which is the coefficient of the initial productivity level, was negative and significant at $1 \%$ level, indicating that low productivity countries are catching up with high productivity countries. In other words, countries with poor level of productivity at the beginning of the period grew faster than the high productivity countries. They took advantage of their backwardness and were able to exploit new technologies and thereby caught up with the best practice frontier. This indicates that technological innovations that increase total factor productivity is a public good that can be transferred from one country to another, facilitating the convergence of total factor productivity. The evidence for the existence of the catching up process (unconditional $\beta$ convergence) in this study is in contrast with the multi-factor productivity results of Thirtle et al (2000) who found a strong evidence that agricultural productivity in Botswana's districts does not converge. In fact, there was divergence and districts with low levels of productivity at the beginning of the period grew less rapidly than the high productivity district during the period 1981-1996.

The existence of $\beta$-convergence implies a longterm catch-up mechanism. However, this mechanism can be offset by temporary shocks which adversely (or favourably) impact short-run dispersion. As a result, $\beta-$ convergence may not be fully reflected in changes of the dispersion of productivity levels (Barro, 1997). This necessitated the need to conduct the $\sigma$-convergence test whose magnitude is measured by the standard deviation of the log of agricultural TFP across countries over time. This was pursued by plotting the cross-sectional standard deviations of TFP growth rates over time. The result is presented in figure 1. From the figure one can observe periods of convergence or divergence through time. 
Table 2: Growth rates of the Malmquist TFP index and its components

\begin{tabular}{|c|c|c|c|c|c|c|}
\hline \multicolumn{4}{|l|}{ Annual means } & \multicolumn{3}{|c|}{ Annual growth rates (\%) } \\
\hline COUNTRY & EFFCH & TECHCH & TFPCH & EFFCH & TECHCH & TFPCH \\
\hline Algeria & 1.048 & 0.674 & 0.706 & 4.80 & -32.60 & -29.40 \\
\hline Egypt & 1.034 & 0.679 & 0.702 & 3.40 & -32.10 & -29.80 \\
\hline Libya & 1.026 & 0.693 & 0.711 & 2.60 & -30.70 & -28.90 \\
\hline Morocco & 1.021 & 0.701 & 0.716 & 2.10 & -29.90 & -28.40 \\
\hline Tunisia & 1.017 & 0.711 & 0.724 & 1.70 & -28.90 & -27.60 \\
\hline Burkina-Faso & 1.014 & 0.741 & 0.752 & 1.40 & -25.90 & -24.80 \\
\hline Gambia & 1.017 & 0.771 & 0.784 & 1.70 & -22.90 & -21.60 \\
\hline Niger & 1.014 & 0.779 & 0.790 & 1.40 & -22.10 & 21.00 \\
\hline Senegal & 1.012 & 0.815 & 0.825 & 1.20 & -18.50 & 17.50 \\
\hline Sudan & 1.010 & 0.846 & 0.854 & 1.00 & -15.40 & -14.60 \\
\hline Burundi & 1.008 & 0.882 & 0.889 & 0.80 & -11.80 & 11.10 \\
\hline Kenya & 1.006 & 0.961 & 0.966 & 0.60 & -3.90 & -3.40 \\
\hline Tanzania & 1.005 & 1.002 & 1.007 & 0.50 & 0.20 & 0.70 \\
\hline Uganda & 1.003 & 1.034 & 1.037 & 0.30 & 3.40 & 3.70 \\
\hline Benin & 1.001 & 1.047 & 1.048 & 0.10 & 4.70 & 4.80 \\
\hline Cote d'Ivoire & 1.000 & 1.067 & 1.067 & 0.00 & 6.70 & 6.70 \\
\hline Ghana & 0.999 & 1.081 & 1.080 & -0.10 & 8.10 & 8.00 \\
\hline Guinea & 0.999 & 1.132 & 1.131 & -0.10 & 13.20 & 13.10 \\
\hline Nigeria & 1.000 & 1.162 & 1.162 & 0.00 & 16.20 & 16.20 \\
\hline Togo & 1.000 & 1.194 & 1.194 & 0.00 & 19.40 & 19.40 \\
\hline Malawi & 1.000 & 1.243 & 1.243 & 0.00 & 24.30 & 24.30 \\
\hline Mozambique & 0.999 & 1.299 & 1.298 & -0.10 & 29.90 & 29.80 \\
\hline Namibia & 1.000 & 1.421 & 1.421 & 0.00 & 42.10 & 42.10 \\
\hline South Africa & 1.000 & 1.471 & 1.471 & 0.00 & 47.10 & 47.10 \\
\hline Zambia & 1.000 & 1.519 & 1.519 & 0.00 & 51.90 & 51.90 \\
\hline Zimbabwe & 1.000 & 1.528 & 1.528 & 0.00 & 52.80 & 52.80 \\
\hline Overall Mean & 1.009 & 0.983 & 0.991 & 0.90 & -1.70 & -0.90 \\
\hline
\end{tabular}

Note: EFFCH=efficiency change, TECHCH=technical change, TFPCH= total factor productivity change. Annual means are geometric means of individual country values and annual growth rates are the value of the TFP index at a point in time minus one which indicates the percentage of growth.

Table 3: Testing for Beta Convergence

\begin{tabular}{lrrrrr}
\hline Period & Variable & Coefficient & Std. error & t-statistics & R-squared \\
\hline 1961-2009 & $\alpha$ & 21.9352 & 5.9497 & $3.690^{*}$ & 0.40 \\
& $\beta$ & -7.3221 & 1.8169 & $-4.303^{*}$ & \\
\hline
\end{tabular}

Note: *Significant at $1 \%$ level $(\mathrm{p}<0.01)$.

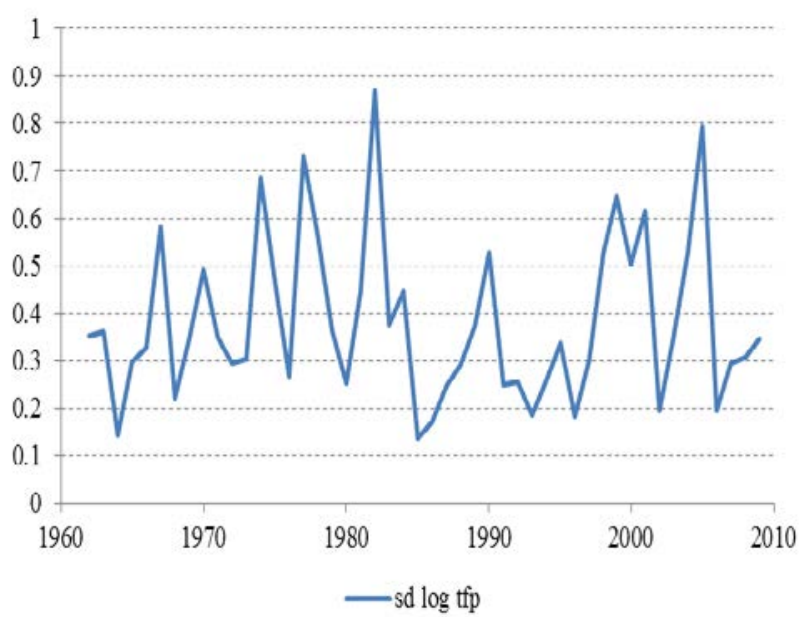

Figure 1. Testing for $\sigma$-Convergence (Standard Deviation of Log of TFP)

This indicates that productivity gap between some low productivity countries and high productivity ones still exist. For example, the standard deviations of the log of TFP showed a steady increase in the dispersion of the cross-sectional standard deviations of the log of TFP after 1964 and then reduced slightly in 1968, the standard deviation reached 0.9 (from 0.34 in 1962), to drop to 0.14 in 1985. This implies a mix of an increase and decrease in the distribution of dispersion in TFP growth rates at cross-sectional level and over the study period. It was found that the result did not confirm the catching up (Beta convergence) result in Table 3. In simple terms, we can say that there is the existence of divergence. A common explanation for rejection of this hypothesis is that $\sigma$-convergence is sensitive to temporary shocks. In the agricultural sector, these could include fluctuation of such variables as demands, disease, or weather conditions.

\section{DISCUSSION AND CONCLUSIONS}

The study applied data drawn from the Food and Agricultural Organization Statistics (FAOSTAT) of the United Nations for a 49-year period (1961-2009) to estimate total factor productivity (TFP) in 26 countries of Africa. The Data Envelopment Analysis (computer) programme (DEAP) developed by Coelli (1996) was used to calculate the TFP Malmquist index and its components: technical efficiency change and technical 
changes over the entire period for each country. Twelve of the twenty-six countries of Africa had negative TFP growth rates over the 1961-2009 period (Algeria, Egypt, Libya, Morocco, Tunisia, Burkina Faso, Gambia, Niger, Senegal, Sudan, Burundi and Kenya).Tanzania had an agricultural TFP growth rate below 1\%. Six had TFP growth rates below 10\% (Uganda, Benin, Cote d'Ivoire and Ghana). While three experienced TFP growth rates above 10\% (Guinea, Nigeria, and Togo). Both Malawi and Mozambique had TFP growth rates above 20\%. Four had TFP growth rates above 40\% (Namibia, South Africa, Zambia and Zimbabwe). The highest productivity growth for the period 1961-2009 was found in the southern countries of Africa-Zimbabwe (52.8\%), Zambia (51.9\%), South Africa (47.1\%), Namibia (42.1\%), Mozambique (29.8\%) and Malawi (24.3\%). This was followed by African countries of the Gulf of GuineaTogo (19.4\%), Nigeria (16.2\%), Guinea (13.1\%), Ghana (8.0\%), Cote d'Ivoire (6.7\%), Benin (4.8\%), Uganda (3.7\%). The TFP measures were then used to estimate the productivity growth rates. Employing a cross section framework, the concepts of $\beta$-convergence, interpreted as catching up and $\sigma$-convergence were tested. An obvious catching up process (unconditional $\beta$ convergence) was evident in Africa during the study period. This was however, not supported by the $\sigma-$ convergence test, which rather showed divergence. From a policy perspective, evidence of $\beta$ - convergence is a positive achievement as it implies catching up of low productivity countries to high productivity ones. However, there was no reduction in national inequality in agricultural productivity in the long-run, given the absence of $\sigma$-convergence. In Africa, mere importation of agricultural technologies, without investment in understanding the principles and uses of technology will not reduce productivity inequalities across countries. There is an urgent need for governments and the private sectors to increase investments in human and institutional capital.

\section{ACKNOWLEDGEMENT}

The initial paper was presented at the $12^{\text {th }}$ GLOBELICS International Conference held at Addis Ababa, Ethiopia on the $29^{\text {th }}-31^{\text {st }}$ October, 2014. We acknowledge with gratitude the funding from SIDA and Aalborg University to support the travel expenses and/or fee reduction in connection with conference participation. We are equally grateful to Prof. Abdeldader Djeflat, of Université de Lille for his helpful suggestions. We also thank all other conference participants who made useful comments to the improvement of this work. We are however, solely responsible for all the remaining errors and shortcomings.

\section{REFERENCES}

ABRAMOVITZ, M. 1986. Catching up, forging ahead, and falling behind, Journal of economic History, 46, 385406. doi: http://dx.doi.org/10.1017/s0022050700046209
ACEMOGLU, D. - ZILIBOTTI, F. 2001. Productivity differences, Quarterly Journal of Economics, 116(2): 563-606. doi: http://dx.doi.org/10.3386/w6879

BARRO, R. - SALA-I-MARTIN, X. 1992. Convergence, Journal of Political Economics vol.100, (2): pp. 223 251. doi: http://dx.doi.org/10.1086/261816

BARRO, R. - SALA-I-MARTIN, X. 1995. Economic Growth, 2nd edition. Cambridge: MA, MIT Press.

BASU, S. - WEIL, D. N. 1998. Appropriate technology and growth, Quarterly Journal of Economics 113 (4): 1025-1054. doi: http://dx.doi.org/10.3386/w5865

BYERLEE, D. 1997. African Food Crisis, Lynee Reinner Publishers Inc; London.

CLARK, N. 2002. Innovation systems, institutional change and the new knowledge market: Implications for third world agricultural development, Economics of Innovation and New Technology Vol. 11 No. 4-5 pp. 353-368.

doi:

http://dx.doi.org/10.1080/10438590200000004

COELLI, T. 1996. Guide to DEAP version 2.1: A data envelopment analysis (computer) Program, CEPA working paper 96/08, Centre for Efficiency and Productivity Analysis, University of New England.

COELLI, T. J. - RAO, D.S.P. 2005. Total factor productivity growth in agriculture: A malmquist index analysis of 93 countries, 1980-2000,” Agricultural Economics 32,115-134. doi: http://dx.doi.org/10.3386/w5865

DAVIS, K. D. - EKBOIR, J. - MEKASHA, W. OCHIENG, C.M.O. - SPIELMAN, D.J.- ZERFU, E. 2007. Strengthening Agricultural Education and Training in Sub-Saharan Africa From an Innovation Systems Perspective: Case Studies of Ethiopia and Mozambique. IFPRI Discussion Paper 00736. International Food Policy Research Institute (IFPRI), Washington, DC.

DELONG J.B. 1988. Productivity growth, convergence and welfare: Comment, American Economic Review 78: 1138-1154. doi: http://dx.doi.org/10.3386/w2419

ELMSLIE, B. T. 1995. Retrospectives : The convergence debate between David Hume and Josiah Tucker Journal of Economic Perspective, 9, 207-216. doi: http://dx.doi.org/10.1257/jep.9.4.207

FAO (Food and Agriculture Organization of the United Nations) $2009 . \quad$ FAOSTAT database. $\leq$ http://www.fao.org/>. Accessed February 15, 2010.

GALLUP J.L.- SACHS, J.D. - MELLINGER, A.D. 1999. Geography and Economic Development, Annual World Bank Conference on Development Economics, Washington D.C.: The World Bank.

GOMULKA, S. 1971. Inventive activity, diffusion and the stages of economic growth, (Skrifter fra Aarhus Universitets Okonomiske Institut, NR.24 ) Aarhus.

GROSSKOPF, S. 1993. Efficiency and productivity in: Fried, Lovell and Schmidt eds; The measurement of productive efficiency (Oxford University Press, New York) 3-67.

GUTIERREZ, L. 2000. Convergence in US and EU agriculture European Review of Agricultural Economics, 27, 187-206. doi: http://dx.doi.org/10.1093/erae/27.2.187 HALL, A. - MYTELKA, L. - OYEYINKA, B. 2006. Concepts and guidelines for diagnostic assessments of 
agricultural innovation capacity. UNU-MERIT Working papers, United Nations University, UNU-MERIT

HAYAMI Y. - RUTTAN, V. 1985. Agricultural Development: An International Perspective. Baltimore, USA: John Hopkins University Press.

KIM, L. 1980. Stages of development of industrial technology in a developing country: A Model Research Policy (9) 254-277. doi: http://dx.doi.org/10.1016/00487333(80)90003-7

LIU, Y., SHUMWAY, I. ROSENMAN, C.R.BALL,V.E. 2010. Productivity growth and convergence in US agriculture: new cointegration panel data results,. Applied Economics, volume 43, Issue 1, 2011.doi: http://dx.doi.org/10.1080/00036840802389087

MANKIW, N.G. - ROMER, D. - WEIL, D. 1992. A contribution to the empirics of economic growth, Quarterly Journal of Economics, 107, 407-37. doi: http://dx.doi.org/10.2307/2118477

MAPILA, M. A. - KIRSTEN, J. F - . MEYER, H. F. 2011, Agricultural rural innovation and improved livelihood outcomes in Africa. Available at: http://www,csae.ox.ac.uk/conferences/2011EDiA/papers/ 017mapila.pdf

NKAMLEU G.B, J. GOKOWSKI AND H.KAZIANGA 2003. Explaining the failure of agricultural production in sub-Saharan Africa, Contributed Paper Selected for Presentation at the 25th International Conference of Agricultural Economists, August 16-22, Durban, South Africa.

RASSEKH, F. - PANIK, M. J. - B. R. KOLLURI. 2001. A test of the convergence hypothesis: the OECD Experience, 1950-1990," International Review of Economics and Finance, 10, 147-157. doi: http://dx.doi.org/10.1016/s1059-0560(01)00079-x
ROSEGRANT, M. W. - AGCAOILI-SOMBILLA, M. PEREZ, N.D. 1992, Global Food Projections to 2020: Implications for Investment. Food, Agriculture, and the Environment: Discussion Paper No. 5. Washington, DC, International Food Policy Research Institute.

SHEPHARD, R. 1970. Theory of Cost and Production Functions. New Jersey: Princeton

University Press.

SOLOW, R. M. 1956. A contribution to the theory of economic growth, Quarterly Journal

of Economics, Vol. 70 (1), pp. 65. doi: http://dx.doi.org/10.2307/1884513

SUHARIYANTO, K. - LUSIGI, A.- THIRTLE, C. 2001."Productivity growth and convergence in Asian and African agriculture." Africa and Asia in comparative economic perspective, Lawrence, P. and C. Thirtle, Palgrave, New York.

THIRTLE, C. - PIESSE, J. - LUSIGI, A. SUHARIYANTO, K. 2003. “Multi-factor agricultural productivity, efficiency and convergence in Botswana, 1981-1996," Journal of Development Economic 71(2):605-624. doi: http://dx.doi.org/10.1016/s03043878(03)00027-0

U.S. department of agriculture (USDA) 2014 "Production, Supply and Distribution." Available at: http://www.usda.gov/psd/psdselection.asp.

WORLD BANK, 2006. Enhancing Agricultural Innovations: How to go Beyond Strengthening Research Systems. Washington, DC. 